\title{
A Deixis Analysis of Song Lyrics in Calum Scott "You Are the Reason"
}

\author{
Elsaria Sitorus*, Herman* \\ Department of English Education, Faculty of Teacher Training and Education, Nommensen HKBP University, Medan, Indonesia \\ Email address: \\ rafelsasr@gmail.com (E. Sitorus), fukadaherman@gmail.com (Herman) \\ ${ }^{*}$ Corresponding author
}

\section{To cite this article:}

Elsaria Sitorus, Herman. A Deixis Analysis of Song Lyrics in Calum Scott "You Are the Reason". International Journal of Science and Qualitative Analysis. Vol. 5, No. 1, 2019, pp. 24-28. doi: 10.11648/j.jjsqa.20190501.14

Received: April 19, 2019; Accepted: June 5, 2019; Published: June 24, 2019

\begin{abstract}
This research is entitled A DEIXIS ANALYSIS OF SONG LYRICS IN CALUM SCOTT "YOU ARE THE REASON". The aims of the mini research is to analyze the kinds ofdeixisand the dominant deixis in song lyrics "you are the reason" by Calum Scott. The discussion began by taking the lyric "you are the reason" as a most popular song in this time. Deixis comes from classical Greek deiknunai. It means to show or point outwhich using to denote those elements in the utterance which for directly to the situation. The study in this paper concerns with the way in which the researcher explains he kinds of deixis and the dominant deixis which used in this lyric. Qualitative research was used as the method of the research. The data used to complete this study is song lyrics. From the data analysis taken from this lyric song, the researcher found in this song, there are 67 words include of kinds of deixis. From the data analysis the researcher found there are three kinds of deixis, they are Person deixis is used to point to objects (it, these, those books), all pronouns (I, you, we), possessives (your, our, their), Spatial deixis used to point to a location (here, there, close to). Temporal in dexicals are expressed in time adverbials like "now, soon, lately, recently, ago, today, tomorrow, yesterday" and the last is Temporal deixis used to point to a time (now, then, next week, last month). Finally, the researcher hopes this research will be useful to sharpen the reader in understanding about deixis.
\end{abstract}

Keywords: Analysis, Deixis, Song, Lyrics

\section{Introduction}

In this world there are some ways to communicate everything, for instance: spoken language, written language, and gesture. It can do with singing, poetry, drama etc. Each person can express ideas among people with them. Sapir in Herman defines language as a purely human and noninstintive method of communicating ideas, emotions and desires by means of a system of voluntarily symbols [1]. Song is a one of the ways to communicate the enables human to cooperate. Song is considered to be a system of communication with other people using sounds and song to express a feeling, sense, idea, emotion or thought.

There are various reasons why people want to use songs in their life and their activities. Some people need it so much to enlarge their business or another projects, to develop their talent, some other people just want to express their feeling, sense, ideas, desire, message and to talk about anything within their communication in any situation.

Based on Cambridge dictionary third edition, lyrics is the words of song, especially a pop song, or a short poem which express the personal thoughts and feelings of the person who wrote it. Its means that not only the arrangement of words into sentence, but also the representation of the composer's sense and emotion to describe their feelings such as desire, struggle, love, ideas and, feeling. There are some messages sent by the composer to the listener with specific situation or context in song lyrics

Related to the lyric in previous paragraph, the lyrics of song which representation of the composer's emotion and intention to describe their feelings such as love, struggle, trouble, jealousy, peace, become a wayto make a beauty communicating. The following example will be given as the illustration. It is taken from the famous song by Calum Scott's song "You are the reason". 


\section{Theoretical Review}

\subsection{Definition of Deixis}

Deixis comes from classical Greek deiknunai, it is meant "to show or point out". Yule states that deixis is actually a technical term (from Greek) which means 'pointing' through language [2]. Then, Cruse stated that deixis means different things to different people [3]. Hence, Bouk discusses that deixis means pointing via language, and it is concerned with the ways in which language encodes the features of the context of utterance or speech event. [4]. In another word is contextual meaning in lexical feature and other grammatical which refers to describe the function of person pronoun, time or place such as he, here, now. Deixis is clearly a form of referring that is tied to the speaker's context. Besides, Lyons states that the term deixis is also used in linguistics function of personal and demonstrative pronouns, and of tense in grammatical and lexical features [5]. It means that a word can be deixis if the referent is nomadic depends on the speaker or time and place pronounced that words, For example:

"Would you mind leaving this class now, please"?

Based on some definitions and example of above, deixis is identification person, place and time that speaker utterance to the hearer based on the context. The lingual elements this and now in one utterance above is deictic expression, because the utterance has meaningful in a given context, in order to be interpreted correctly, the speaker and listener have to share the same context and it is particularly useful in face to face communication.

According to Lyons, deixis is the location and identification of people, object, events, process and activities which is being talked about or referred to, in relation to the time, when the speaker says the utterance, or when the hearer hears it [6]. It means that deixis is a word, or expression that the reference wolves depending on the identity of the speaker, time, place in relation to the utterance.

\subsection{Types of Deixis}

According to Levinson, there is a deictic centre that consists of I, Here and Now [7]. As a result, there are three main categories of deixis:

\subsubsection{Person Deixis}

Person deixis isused to point to objects (it, these, those books), allpronouns (I, you, we), possessives (your, our, their). Person deixis concerns the person involved in an utterance, such as: the persons directly involved. e.g. the speaker and the addressed, the persons not directly involved e.g. those who hear the utterance but are not being directly addressed and the persons mentioned in the utterance. Person deixis is commonly expressed by the following kinds of constituents:

a. First person deixis

First person deixis is deictic reference that refers to the speaker or both the speaker and referents grouped with the speaker e.g. singular pronouns (I, me, myself, my, mine), plural pronouns (we, us, ourselves, our, ours) [7]. Kinds of First person deixis:

i. Exclusive First person deixis

Exclusive First person deixis is deixis that refers to a group not including the addressee (any of immediate intended recipients of the speaker's communication, as grammaticalized in second person morphemes)

ii. Inclusive First person deixis

Inclusive First person deixis is deixis that refers to a group including the addressee

b. Second Person deixis

Second Person deixis is deictic reference to a person or persons identified as addressee. Examples: you, yourself, yourselves, your, yours.

c. Third Person deixis.

Third Person deixisis deictic reference to a referent not identified as the speaker or addressee, e.g. he, she, they, the third person singular verb suffix-s. Kinds of third person deixis:

\section{i. Obviative Person deixis}

Obviative Person deixis is third person deixis that distinguishes a less important referent in the present stage of the discourse from a referent that is more important.

\section{ii. Proximate Person deixis}

Proximate Person deixis is third person deixis that distinguishes a referent that is more important at the present stage of the discourse from a referent that is less important.

\subsubsection{Spatial Deixis}

Thomas stated that spatial deixis or place deixis does not mean in isolation, it is only when you know where the speaker is standing or what the speaker is indicating that it becomes truly meaningful [8]. Hence, Levinson defines spatial deixis as "the encoding of spatial locations relative to the location of participants in the speech event [7]. He adds that most language make us of two term system. The idea of speaker's pointing in space or time in order to draw the attention of the addressee to it is basic to both spatial and temporal deixis. They indicated and proximity from the speaker, physical distance or proximity, mental and psychological distance or proximity, Examples:

i. The hospital is four hundred miles from the bus station

ii. Bring that here and take this there

Place deixis, also known as space deixis, concerns itself with the spatial locations relevant to an utterance. Similarly to person deixis, the location may be either those of the speaker and addressee or those of person or object being referred to. The most salient English examples are the adverbs "here" and "there" and the demonstratives "this" and "that" and these are used to mark the movement towards the speaker, examples:

i. The theater is behind the town hall

ii. I enjoy living in this village

iii.Here is where we will place the statue.

iv. She wassitting over there.

v. Here is a good spot, it too sunny over there.

Older texts have various distinct expressions. Yonder 
(more distant) hither (to this place) and thence (from that place) which are still applicable but archaic. Some verbs of motion 'come' and 'go' retain a deictic sense which means towards the speaker and away from the speaker. These are commonly used for pointing the position of people.

i. The word that seem to be the first deictic meaning.

ii. This and here (can be seen).

iii. That and there (cannot be seen).

iv. This is my book lying here

v. That building is there in Switzerland.

It is important to remember that location from the speaker's perspective can be fixed mentally as well as physically. People away from there homes use 'here' to show and mean their home location.

\subsubsection{Temporal Deixis}

Temporal deixisused to point to a time (now, then, next week, last month) In order to interpret allthese deictic expressions we must know which person, time and place the speaker has in mind. Temporal in dexicals are expressed in time adverbials like "now, soon, lately, recently, ago, today, tomorrow, yesterday" [3]. There is a great difference on what is close to the speaker (this, here, now) and what is distant (that, there, then). We can also realize whether there is a movement away from the speaker (go) orthere is a movement towards the speaker (come). If somebody is moving towards you, you say: Heis coming! If somebody is moving away from you, you say: He is going!

\section{Research Method}

\subsection{Research Design}

The aim of this research is to analyze the types of deixis and the dominant deixiswhich found in the famous song by Calum Scott's song "You are the reason". The method used in this research is qualitative researchmethod, and the source data used is thesong by Calum Scott's song "You are the reason". To complete this research, the researcher uses Cohen et al. theory. Cohen et al. offer some steps of analysis namely: (1). Generating natural unit of meaning, (2). Classifying, categorizing and ordering these units of meaning, (3). Structuring narratives to describe the contents of the speech, and (4). Interpreting the data. [9]

\subsection{Unit of Analysis}

As the unit of analysis, the researcher focuses on the lyric in the song "You are the reason" by Calum Scott's song which is taken from internet.

\subsection{Data Source}

The data were taken from the lyric song "You are the reason" by Calum Scott's song. There are 67 the deixiswords will be analyzed and classified.

\subsection{Technique of Data Analysis}

The data of this study were taken from the lyric song "You are the reason" by Calum Scott's especially the kinds and dominant deixis which found in this lyric, and the researcheruses listen and take notes technique for collecting data. The researcher uses two steps in data collecting. First, listening technique by listen the song several times, then the researcher uses taking notes technique to find out the kinds of deixis by use the data card that was prepared before.

\section{Findings and Discussion}

\subsection{Research Findings}

After analyzing the data, the researcher found some lyric which taken from the lyric song "You are the reason" by Calum Scott's song" shows deixis word expressed in this song. The researcher uses some steps in this research. First, the researcher transcribes the lyric and the second the researcher tabulating the classifying the deixis into person deixis, spatial and temporal deixis, and the last is the researcher draws general interpretation on the lyric. It can be proven by following tables below:

Table 1. Deixis analysis.

\begin{tabular}{|c|c|c|}
\hline NO & Lyric of song & Types of Deixis \\
\hline \multirow{5}{*}{1.} & There goes my heart & There (Spatial Deixis ), my (First \\
\hline & Cause you are the reason. & You (second Person deixis ) \\
\hline & I'm locing musloon & I (first Person deixis), my (First \\
\hline & Tm losing my sleep. & Person deixis ) \\
\hline & Please come back now & Now (TemporalDeixis ) \\
\hline \multirow{4}{*}{2.} & And there goes my mind & There (Spatial Deixis ), my (First \\
\hline & $\begin{array}{l}\text { racing. } \\
\text { And you are the reason. }\end{array}$ & $\begin{array}{l}\text { Person deixis ) } \\
\text { You (second Person deixis ) }\end{array}$ \\
\hline & That I'm still breathing. & $\begin{array}{l}\text { That (Spatial Deixis ), I (first Person } \\
\text { deixis), }\end{array}$ \\
\hline & I'm hopeless now. & $\begin{array}{l}\text { I (first Person deixis), Now } \\
\text { (TemporalDeixis ) }\end{array}$ \\
\hline \multirow{6}{*}{3.} & I'd climb every mountain. & $\begin{array}{l}\text { I (first Person deixis), mountain } \\
\text { (Spatial Deixis) }\end{array}$ \\
\hline & And swim every ocean. & Ocean (Spatial Deixis ) \\
\hline & Just to be with you. & You (second Person deixis ) \\
\hline & And fix what I've broken. & I (first Person deixis), \\
\hline & $\begin{array}{l}\text { Oh, cause I need you to } \\
\text { see. }\end{array}$ & $\begin{array}{l}\text { I (first Person deixis), You (second } \\
\text { Person deixis) }\end{array}$ \\
\hline & Thatyou are the reason. & $\begin{array}{l}\text { That (Spatial Deixis), You (second } \\
\text { Person deixis) }\end{array}$ \\
\hline \multirow{5}{*}{4.} & $\begin{array}{l}\text { There goes Myhands } \\
\text { shaking. }\end{array}$ & $\begin{array}{l}\text { There (Spatial Deixis ), my (First } \\
\text { Person deixis ) }\end{array}$ \\
\hline & And you are the reason. & You (second Person deixis ) \\
\hline & My heart keeps bleeding. & my (First Person deixis ) \\
\hline & & I (first Person deixis), You (second \\
\hline & I need you now & $\begin{array}{l}\text { Person deixis), Now (Temporal } \\
\text { Deixis) }\end{array}$ \\
\hline \multirow{4}{*}{5 . } & $\begin{array}{l}\text { If I could turn back the } \\
\text { clock. }\end{array}$ & I (first Person deixis), \\
\hline & $\begin{array}{l}\text { I'd make sure the light } \\
\text { defeated the dark. }\end{array}$ & I (first Person deixis), \\
\hline & $\begin{array}{l}\text { I'd spend every hour, of } \\
\text { every day. }\end{array}$ & $\begin{array}{l}\text { I (first Person deixis), every hour, } \\
\text { (temporal deixis), every day } \\
\text { (Temporal deixis) }\end{array}$ \\
\hline & Keeping you safe. & You (second Person deixis ) \\
\hline \multirow[t]{2}{*}{6.} & I'd climb every mountain. & $\begin{array}{l}\text { I (first Person deixis), mountain } \\
\text { (Spatial deixis) }\end{array}$ \\
\hline & And swim every ocean. & Ocean (Spatial deixis) \\
\hline
\end{tabular}




\begin{tabular}{|c|c|c|}
\hline NO & Lyric of song & Types of Deixis \\
\hline \multirow{8}{*}{7.} & Just to be with you. & You (second Person deixis ) \\
\hline & And fix what I've broken. & I (first Person deixis), \\
\hline & Oh. cause I need you to & I (first Person deixis), You (second \\
\hline & see & Person deixis) \\
\hline & Thatyou are the reason & $\begin{array}{l}\text { That (Spatial Deixis), You (second } \\
\text { Person deixis) }\end{array}$ \\
\hline & $\begin{array}{l}\text { I don't want to fight no } \\
\text { more }\end{array}$ & I (first Person deixis) \\
\hline & $\begin{array}{l}\text { I don't want to hide no } \\
\text { more }\end{array}$ & I (first Person deixis) \\
\hline & $\begin{array}{l}\text { I don't want to cry no } \\
\text { more }\end{array}$ & I (first Person deixis) \\
\hline \multirow{6}{*}{8.} & $\begin{array}{l}\text { Come back, I need you to } \\
\text { hold me }\end{array}$ & $\begin{array}{l}\text { I (first Person deixis), You (second } \\
\text { Person deixis), me (first personal } \\
\text { deixis) }\end{array}$ \\
\hline & (you are the reason) & You (second Person deixis ) \\
\hline & A little closer now & Now (TemporalDeixis ) \\
\hline & Just a little closer now & Now (TemporalDeixis ) \\
\hline & Come a little closer & --- \\
\hline & $\begin{array}{l}\text { I need you to hold } \\
\text { metonight }\end{array}$ & $\begin{array}{l}\text { I (first Person deixis), You (second } \\
\text { Person deixis), me (first person } \\
\text { deixis), tonight (temporal deixis ) }\end{array}$ \\
\hline \multirow{6}{*}{9.} & I'd climb every mountain. & $\begin{array}{l}\text { I (first Person deixis), mountain } \\
\text { (Spatial deixis) }\end{array}$ \\
\hline & And swim every ocean. & Ocean (Spatial deixis) \\
\hline & Just to be with you. & You (second Person deixis ) \\
\hline & And fix what I've broken. & I (first Person deixis), \\
\hline & cause I need you to see & $\begin{array}{l}\text { I (first Person deixis), You (second } \\
\text { Person deixis) }\end{array}$ \\
\hline & That you are the reason & $\begin{array}{l}\text { That (Spatial Deixis), You (second } \\
\text { Person deixis) }\end{array}$ \\
\hline
\end{tabular}

Table 2. Deixis kinds in The lyric song "you are the reason".

\begin{tabular}{llll}
\hline no & deixis kinds & Quantity & percentages \\
\hline 1. & Person deixis & 46 & $68,75 \%$ \\
2. & Spatial deixis & 13 & $18,75 \%$ \\
3. & Temporal deixis & 8 & $12 \%$ \\
& total & 67 & $99,5 \%$ \\
\hline
\end{tabular}

From the table above, it can be seen that the large number thekinds of deixiswhich found in the lyric song "you are the reason" are: Persondeixis 68,75\%, Spatial deixis: 18,75\%, Temporal deixis: $12 \%$. The highest percentage of all is Person deixis, it means that the dominant of deixis which use in the lyric song "You are the reason" by Calum Scott's song" is Person deixis.

\subsection{Discussion}

The researcher found 46 or $68,75 \%$, deixis in the Person deixis, 13 or $18,75 \%$ Spatial deixis, 8 or $12 \%$ Temporal deixisin the the lyric song "You are the reason" by Calum Scott's song". The researcher found 67 words of deixis. 46 or $68,75 \%$, deixis in the Person deixis, 13 or $18,75 \%$ Spatial deixis, 8 or $12 \%$ Temporal deixisin the lyric song "You are the reason" by Calum Scott. The discussions from the researcher is about the large number deixis or the kinds of deixis which used in any lyric of songs is different. It means that the kind of deixisused is depending to the composer's sense and emotion to describe their feelings in the lyric of song that they wrote.

After analyzing the data above, the researcher found that the dominantof deixisin the lyric song "You are the reason" by Calum Scott's songis Personal deixis. The next dominant is Spatial deixis, it can be see in the table 2. It means that the large number deixis which used in the lyric song "You are the reason" by Calum Scott is Personal deixis.

\section{Conclusion}

After describing an overview about the kinds of deixisin the lyric song "You are the reason" by Calum Scott, some conclusions are drawn as the following:

i. Based on the lyric song "You are the reason" by Calum Scott, the kinds of deixis are found in that lyric, they are: persondeixis, spatial deixis, temporal deixis.

ii. The dominant deixis in the lyric song "You are the reason" by Calum Scottis person Deixis.

\section{References}

[1] Herman. (2014). An Experiential Function on Students' Genre of Writing. Jakarta: Halaman Moeka Publishing.

[2] Cruse, Alan D. (2000). Meaning in Language: An Introduction to Semantics and Pragmatics. New York: Oxford University Press.

[3] Yule, G. (1996). Pragmatics. New York: Oxford University Press.

[4] Bouk, E. (2016). Pragmatic Analysis of Deixis in the Speeches of Xanana Gusmao-The former prime minister of Timor Leste. Jurnal Tutur. Vol. 2, No. 2 Agustus 2016. ISSN 2442-3475

[5] Lyons, J. (1977a). Semantics, Vols 1 \& 2. Cambridge: Cambridge University Press.

[6] Lyons, J. (1983). Introductions to Theoretical Linguistics. London: Cambridge University Press.

[7] Levinson, Stephen C. (1983). Pragmatics. London: Cambridge University Press.

[8] Thomas, J. (1995). Meaning in Interaction an Introduction to Pragmatics. Essex: Longman.

[9] Cohen, L. (2007). Research Methods in Education. London: Routledge.

[10] Anderson, Stephen R. \& Edward L. Keenan. (1985). 'Deixis', in: Timothy Shopen (ed.) Language Typology and Syntactic Description III: Grammatical categories and the lexicon, 259308, Cambridge University Press.

[11] Coulthard, Malcolm. (2014). An Introduction to Discourse Analysis. Second Edition. London and New York: Routledge Taylor and Francis Group.

[12] Gee, James Paul. (2011). An Introduction to Discourse Analysis: Theory and Method, Third Edition. London and New York: Routledge Taylor and Francis Group.

[13] Fairclough, N. L. (1995). Critical discourse analysis: The critical study of language. Harlow, UK: Longman.

[14] Halliday, M. A. K. (1985). Spoken and written language. Oxford: Oxford University Press. 
[15] Herman. (2015). Illocutionary Acts Analysis of Chinese in Pematangsiantar. International Journal of Humanities and Social Science Invention. ISSN (Online): 2319-7722, ISSN (Print): 2319-7714, Volume 4 Issue 12, PP. 41-48.

[16] Hutajulu, F. S. L. and Herman. (2019). Analysis of Illocutionary Act in the Movie "You are My Home" English Subtitle. Journal of English Educational Study, Volume 2
Issue 1 May 2019, Page 29-36, 2019. DOI: 10.31932/jees. v2i1.371.

[17] Martin, J. R \& Rose, D. (2003). Working with discoursemeaning beyond the clause. Great. 